\title{
Morphological diversity of Zacatecas Guajillo chile landraces is broad and is given mainly by fruit traits
}

\author{
Yolanda del Rocio Moreno-Ramírez', Amalio Santacruz-Varela1, Pedro A. López², Higinio López- \\ Sánchez ${ }^{2 *}$, Leobigildo Córdova-Téllez', Víctor A. González-Hernández ${ }^{1}$, Tarsicio Corona-Torres', \\ Ricardo López-Ortega ${ }^{3}$
}

${ }^{1}$ Colegio de Postgraduados, Campus Montecillo. Texcoco, Estado de México, México, ${ }^{2}$ Colegio de Postgraduados, Campus Puebla. San Pedro Cholula, Puebla, México, ${ }^{3}$ Universidad Autónoma Chapingo. Texcoco, Estado de México, México

\section{A B S TR A C T}

Guajillo (Capsicum annuum L.) is one of the five more important chile types used as food in Mexico and the most important to local economy in Zacatecas, whose production is supplied mainly by native populations. In spite of this, not much is known about the morphological diversity of Guajillo landraces of Zacatecas. Here, we describe and quantify their morphological variation in order to establish breeding programs and to preserve the phenotypic diversity. Thirty-two plant, flower, fruit, seed and phenological traits were assessed in 96 Guajillo chile landraces and four improved varities of Guajillo used as controls, grown during the 2015 agricultural cycle in Zacatecas, Mexico. The selection of variables was made based on the analysis of variance and multivariate analysis that were applied to the selected variables to estimate the morphological diversity. A wide variation of plant, fruit and seed characteristics was identified. This morphological heterogeneity is attributed mainly to fruit traits such as: size, weight, shape, color, transverse wrinkling of the fruit, shape of the peduncle and the number of fruits produced. This wide morphological diversity can potentially be utilized in the genetic improvement of Guajillo chile.

Keywords: Capsicum annuum L.; Guajillo chile; Morphological diversity; landraces; Mexico.

\section{INTRODUCTION}

Chile peppers (Capsicum annum L.) are highly valued for their aroma, flavor and piquant spiciness. They are outstanding worldwide for their wide distribution, economic importance and morphological diversity (Wang \& Bosland, 2006). Mexico, being the center of domestication and diversity, has large variety of wild types (Aguilar-Meléndez et al., 2009; Kraft et al., 2014) and landraces grouped as cultivated chile types that are dynamic and highly heterogeneous (Mercer and Perales, 2010). Morphological and genetic diversity of chile landraces has depended on human selection, management and use of its characteristics. This large variation has been generated by agronomic and natural selection in each region and agrosystem (Petropoulos et al., 2019). Their populations satisfy different demands such as: cultivar type, color, shape, ripeness and pungency, and even particular purposes of the farmer, such as the period of dehydration and dry weight in the case of dried chiles (Kraft et al., 2010).
Each type of chile has its own morphological characteristics, flavor and adaptation to specific environments (Bhagowati \& Changkija, 2009) and represents reservoirs of genetic diversity that has not been fully exploited (Rivera et al., 2016); for example, native populations preserve private alleles of agricultural interest and agroadaptation (GonzálezPérez et al., 2014) to specific environments (Portis et al., 2004), as in the case of Poblano chile (Contreras-Toledo et al., 2011) and chile de Agua (Martínez-Sánchez et al., 2010).

Description, quantification and classification of morphological diversity of native populations will allow genetic valuation and conservation (Chávez-Servia, 2006), as well as effective and efficient use of the germplasm of interest for plant breeding programs (Afzal et al., 2018). Morphological diversity on landraces of C. annuum in Mexico has been assessed, for example, in XCat'ic, Dulce, Ya'ax ic, Succurre, Cha'huá, Maaxito and Habanero from Yucatán (Latournerie et al., 2002), Poblano (Toledo-Aguilar

\footnotetext{
${ }^{*}$ Corresponding author:

Higinio López-Sánchez, Colegio de Postgraduados, Campus Puebla. San Pedro Cholula, Puebla, México.

E-mail: higiniols@colpos.mx
}

Received: 21 February 2019; Accepted: 12 May 2019 
et al., 2011), Ancho (Toledo-Aguilar et al., 2016), de Agua, Tabiche, Tusta, Piquín, Solterito and Nanche from Valles Centrales de Oaxaca (Castellón-Martínez et al., 2016). All of them conclude that traits of plant, fruit and postharvest physical characteristics contribute more to the morphological diversity. Moreno-Perez et al. (2011) assessed the morphological diversity of Guajillo chile, but it has three disadvantages: i) they collected a small group of landraces (32) from the states of Zacatecas and Durango, ii) the experiment was just established in one locality and iii) the evaluation was done in the state of Mexico, out of the region where landraces are grown. In order to have a more precise assessment of the morphological diversity in Guajillo chile, the research had to consider a larger amount of landraces, at least two experimental sites and to be done in the region where landraces are grown to assure a better expression of the Guajillo chile features (Gil-Muñoz et al., 2004).

In Mexico, Zacatecas is the most important producer of dried chiles such as Guajillo (SIAP-SAGARPA, 2017). In the cultivation of chile it contributes $35 \%$ of the economic value of the agricultural sector (Serna-Pérez et al., 2011); $80 \%$ of production is sold dried, and among the dried chiles, Guajillo is outstanding. Management, cultivation and use of native landraces of Guajillo is widespread in the region; however, their genetic diversity has not been assessed enough. As a consequence, we do not know if it is broad, reduced or in risk, and if there are landraces with agronomic potential to increase traits such as fruit yield.

Given the economic and genetic importance of Guajillo chile (Moreno-Pérez et al., 2006, 2007, 2011), studies on its morphological diversity and on the agronomic and breeding potential of native landraces are required. It is recommendable that the studies be conducted in the chile producer regions, with the corresponding agronomic management and practices used by the farmers who preserve and use the germplasm. Moreover, research developed in this way would allow identification of landraces with agronomic characteristics that may have potential for initiating strategies of management, conservation and breeding in conditions where they have been selected and adapted over long periods of time (Mercer \& Perales, 2010). The objectives of this study carried out on Guajillo chile landraces were to know its morphological diversity level and to determine the plant traits with significant contribution to the morphological diversity.

\section{MATERIALS AND METHODS}

Genetic material. Seeds were extracted from dry fruits of 96 native varieties, collected in Zacatecas, Durango, and Puebla
(Figure in Annex 1). In addition, four improved varieties of Guajillo chile were included as controls for morphological diversity analyses: three of them (Don Ramón, Don Luis and VR91) were developed by the Instituto Nacional de Investigaciones Forestales, Agrícolas y Pecuarias (INIFAP), and the commercial hybrid Castillo ${ }^{\mathbb{B}}$ was developed by the MarSeed Company.

Experimental site and management. In the 2012 springsummer growing season, 45-day-old seedlings were planted in plots belonging to collaborating farmers in two locations of the state of Zacatecas: (i) Rancho San Felipe, Fresnillo $\left(23^{\circ} 10 \mathrm{~N}\right.$ and $103^{\circ} 04 \mathrm{~W}$, altitude 2060 meters above sea level -masl-) and (ii) Casa Blanca, Guadalupe $\left(22^{\circ} 86 \mathrm{~N}\right.$ and $102^{\circ} 31 \mathrm{~W}$, altitude $2050 \mathrm{masl}$ ). Agronomic management was similar to that traditionally carried out in the region. On Rancho San Felipe, the crop was established with plastic cover and ferti-irrigation with 180N-90P-00K fertilizer at trasplanting. During plant development fertilizer was applied by ferti-irrigation. In Casa Blanca, surface irrigation was used with $80 \mathrm{~N}-100 \mathrm{P}-50 \mathrm{~K}$ in the first weeding, 80-00-50 at flowering and 60-00-50 at fruit set. Weed control was done manually in both sites.

Experimental design and experimental unit. The experimental design used was a $10 \times 10$ lattice with two replications. The experimental unit consisted of $4 \mathrm{~m}$ long double rows in which 40 plants were established, two plants per hill $0.40 \mathrm{~m}$ apart. Distance between rows was $0.76 \mathrm{~m}$; plant density was 52,632 plants ha- ${ }^{-1}$.

Assessed traits. In a sample of 10 representative plants from each experimental unit, the traits assessed corresponded to the following five morphological categories taken from the descriptors guide for Capsicum (IPGRI-CATIEAVRDC, 1995): i) Plant traits: anthocyanins in nodes (1: green, 3: light purple, 5: purple, 7: dark purple); stem pubescence (3: little, 5: intermediate, 7 : dense); plant height $(\mathrm{cm})$; stem length $(\mathrm{cm})$; stem diameter $(\mathrm{cm})$; number of bifurcations; number of branches in the first bifurcation; number of secondary branches; ratio width/length of the mature leaf. ii) Flower traits: corolla spot colour (1: white, 2: yellow, 3: yellowish green, 4: green, 5: purple); anther length (mm); filament length ( $\mathrm{mm})$; number of petals. iii) Fruit traits: color of immature fruit (3: green, 4: orange, 5: purple, 6: dark purple); color of mature fruit (7: light red, 8: red, 9: dark red, 10: purple, 11: brown, 12: black); fruit shape (1: elongated, 2: almost round, 3: triangular, 4: campanulate, 5: blocky); fruit length $(\mathrm{cm})$; fruit width $(\mathrm{cm})$; pedicel length $(\mathrm{cm})$; pericarp thickness $(\mathrm{mm})$; fruit shape at pedicel attachment (1: acute, 2: obtuse, 3: truncate, 4: cordate, 5: lobate); fruit cross-sectional corrugation (3: slightly corrugated, 5: intermediate, 7: corrugated); number of fruit locules; placenta length $(\mathrm{mm})$; varietal mixture 
Table 1: Information of the localities where Guajillo chile landraces were collected

\begin{tabular}{|c|c|c|c|c|c|c|c|}
\hline State (\#) & LN & LW & Altitude & Climate & Vegetation & Landraces & Total \\
\hline \multirow[t]{18}{*}{ Zacatecas (6) } & 22.95 & -102.72 & 2187 & BS1kw & $\begin{array}{l}\text { Annual and permanent irrigation } \\
\text { agriculture }\end{array}$ & $\begin{array}{l}\text { G702, G703, G716, G717, G738, } \\
\text { G739, G784, G789, G794, G795 }\end{array}$ & 10 \\
\hline & 22.92 & _102.8 & 2243 & BS1kw & Annual rainfed agriculture & $\mathrm{G} 780, \mathrm{G} 781$ & 2 \\
\hline & 22.92 & -102.72 & 2190 & BS1kw & Annual rainfed agriculture & G791 & 1 \\
\hline & 22.99 & -102.72 & 2151 & BS1kw & Annual rainfed agriculture & G777, G786, G792, G793, G796, & 5 \\
\hline & 23.01 & _102.76 & 2162 & BS1kw & Annual rainfed agriculture & G785, G787, G788 & 3 \\
\hline & 23.35 & -102.96 & 2072 & BS1kw & Annual rainfed agriculture & G701 & 1 \\
\hline & 23.46 & -102.92 & 2068 & BS1 kw & Annual rainfed agriculture & G722 & 1 \\
\hline & 24.73 & -102.75 & 2079 & BWhw & Desertic shrubs & G704-G706, G718, G720 & 5 \\
\hline & 23.19 & _102.81 & 2120 & BS1kw & Annual irrigation agriculture & G790 & 1 \\
\hline & 22.88 & -102.67 & 2194 & BS1kw & Annual irrigation agriculture & G779 & 1 \\
\hline & 22.87 & -102.62 & 2264 & BS1kw & Annual rainfed agriculture & G707 & 1 \\
\hline & 23.2 & -102.84 & 2298 & BS1kw & $\begin{array}{l}\text { Natural pastureland arbustive } \\
\text { secondary vegetation }\end{array}$ & G736 & 1 \\
\hline & 23.45 & _102.95 & 2009 & BS1kw & Secondary arbustive grassland & G723-G725 & 3 \\
\hline & 25.21 & - 104.14 & 2340 & BWhw & $\begin{array}{l}\text { Semi-permanent and } \\
\text { permanent irrigation agriculture }\end{array}$ & G782 & 1 \\
\hline & 25.13 & -103.78 & 2173 & BWhw & $\begin{array}{l}\text { Vegetation secondary arbustive } \\
\text { of desertic matorral }\end{array}$ & G778 & 1 \\
\hline & 22.87 & _102.53 & 1973 & BS1kw & Natural pastureland & G708-G715 & 8 \\
\hline & 22.91 & -102.48 & 1995 & BS1kw & Annual rainfed agriculture & $\begin{array}{l}\text { G741-G756, G757, G758, } \\
\text { G759-G776, G797-G801 }\end{array}$ & 41 \\
\hline & 24.07 & _104.57 & 1855 & BS1kw & Annual irrigation agriculture & $\mathrm{G} 740$ & 1 \\
\hline \multirow[t]{4}{*}{ Durango (2) } & 23.98 & _104.71 & 1864 & BS1kw & $\begin{array}{l}\text { Natural pastureland arbustive } \\
\text { secondary vegetation }\end{array}$ & G729-G731 & 3 \\
\hline & 23.19 & -102.32 & 1956 & BS1kw & Annual rainfed agriculture & G726, G727 & 2 \\
\hline & 23.07 & -102.25 & 1571 & BS1kw & Annual rainfed agriculture & G732 & 1 \\
\hline & 23.84 & -103.04 & 1300 & BSokw & Annual rainfed agriculture & G734, G735 & 2 \\
\hline Puebla (1) & 19.14 & _98.465 & 2485 & C (w2) & $\begin{array}{l}\text { Annual rainfed and permanent } \\
\text { agriculture }\end{array}$ & G721 & 1 \\
\hline
\end{tabular}

(\#): Number of localities; Altitude: m (meters above sea level); LN: Latitude; LW: Longitude; G: Guajillo

condition (3: slight; 5 , intermediate; 7 : important); average dry weight (g); number of fruits per plant. iv) Seed traits: seed diameter (mm); number of seeds per fruit; weight of 1000 seeds (g). v) Phenological traits: days to flowering (50\% of plants of experimental unit with one flower); days to fruiting $(50 \%$ of plants of experimental unit with one fruit).

Statistical analysis. Continuous and categorical data were analyzed simultaneously. To determine the effects of the interaction genotype $\times$ environment interaction, a combined analysis of variance was performed across locations. Correlation analysis between statistically significant traits $(\mathrm{p} \leq 0.05)$ was performed for pairs of traits with a coefficient of correlation above 0.7 , and only one was selected (Pla, 1986).

The traits with high descriptive value constituted the matrix used in the multivariate analyses. A principal component analysis (PCA) was performed. Using the non-parametric method Modeclus (SAS, 2011), genotype distribution was plotted using the first two PC, in which the genotype density estimator $(r)$ defined the number of significant groups. A cluster analysis, with the Modified Location Method (Ward-MLM), defined genotype groups by the Ward minimum variance hierarchy (SAS, 2011), based on the dissimilarity matrix of Gower. The MLM was used to establish the ideal number of groups based on the means of the values for each trait in each sub-group (Franco et al., 2005), based on pseudo-F and pseudo- $\mathrm{t}^{2}$ statistics and the logarithmic function of probability (Log-L). Means of the resulting groups were compared (Tukey $\mathrm{p} \leq 0.05)$. The analyses were performed in SAS V.9.4 software (SAS. 2011).

\section{RESULTS}

Distribution of morphological diversity. Significant differences were found in $72 \%$ of the morphological traits analyzed, which is an indicator of broad morphological diversity on Guajillo chile landraces. Only nine of the vegetative descriptors did not present significative effects. The most important statistically significant correlations among the 23 traits were associated with fruit traits. Fiftythree percent of the 32 traits contributed information on morphological diversity. 
The analyses of variance and correlation identified 17 highly discriminating characteristics that explained $76.9 \%$ of the total variation with five principal components (Table 2).

Fruit traits were more powerful discriminators than those of plant and floral structures. The main contribution of morphological diversity is described particularly with eleven fruit characteristics, $65 \%$ of the selected vegetative traits. Width, length, weight, number of fruits per plant and shape of the fruit, as well as placenta length and pedicel length explained most of the phenotypical heterogeneity observed. In contrast, floral structures and some plant characteristics such as the presence of anthocyanins, stem length and diameter and number of branches did not contribute to the morphological variation description.

According to the populations distribution on the plane determined by PC1 and PC2 (Figure 1), broad coverage is markedly associated with the fruit. A dispersion gradient between Quadrants I and III was observed where the populations G790 and the VR91 exhibited opposite behavior related to plant, fruit and seed size traits. This determined their location at each end of the dispersion. The trend began with VR91, which had small plant, short, narrow, and lightweight fruits and small seeds. In contrast, the landrace G790 was placed at the end of the cluster, having wider, heavier and longer fruits that produced large seeds. In the middle of the gradient, near the intercept, were located populations from Zacatecas and Durango, together with commercial cultivars, which showed intermediate behavior and whose continuous variation indicated similarity in their phenotypical variation. This contrasted with four Guajillo-type populations dispersed throughout Quadrant IV and widely separated from the trend.

Estimation density, based on a radius of 2.5 obtained by the Modeclus procedure, defined three groups over the spatial distribution (Figure 1), which is an indicator of the broad phenotypical heterogeneity.

The highest density of landraces was observed in Group 1: 92 native landraces, two improved materials (L: Don Luis and R: Don Ramón) and the commercial hybrid. Morphological diversity in terms of plant height, fruit length, width, weight, number of fruits per plant and placenta length with obtuse pedicel and seed number together with their distribution in central part of plane through the four quadrants indicated broad morphological diversity of the Guajillo complex.

Quadrant III concentrated 30 genotypes with short plants and short, narrow, and lightweight fruits with reduced placenta and pedicel, together with the improved materials Don Luis (L) and Don Ramón (R), VR9 and the hybrid which had similar attributes. In contrast, 28 landraces that showed these characteristics of greater magnitude were placed in Quadrant I. Moreover, around the origin, with greater tendency toward Quadrant II, 31 varieties of intermediate size were positioned.

Table 2: Eigenvectors of the first five principal components derived from 17 characteristics of Capsicum annuum L.

\begin{tabular}{|c|c|c|c|c|c|}
\hline \multirow[t]{2}{*}{ Characteristic } & \multicolumn{5}{|c|}{ Eigenvectors } \\
\hline & PC1 & PC2 & PC3 & PC4 & PC5 \\
\hline Plant height & 0.107 & 0.382 & 0.341 & 0.063 & 0.287 \\
\hline Fruit width & 0.327 & -0.088 & -0.006 & -0.082 & 0.232 \\
\hline Fruit cross-sectional corrugation & 0.272 & -0.246 & 0.134 & -0.109 & -0.103 \\
\hline Color of ripe fruit & 0.016 & 0.115 & 0.340 & -0.597 & -0.312 \\
\hline Days to fruit set & 0.021 & 0.057 & 0.644 & 0.412 & -0.221 \\
\hline Seed diameter & 0.256 & 0.246 & -0.125 & 0.072 & -0.231 \\
\hline Stem diameter & 0.148 & 0.263 & -0.290 & -0.119 & 0.342 \\
\hline Fruit shape & 0.333 & -0.212 & 0.043 & 0.158 & 0.033 \\
\hline Fruit shape at pedicel attachment & 0.358 & -0.111 & 0.009 & 0.165 & 0.013 \\
\hline Number of fruits per plant & -0.239 & -0.234 & -0.017 & -0.038 & 0.379 \\
\hline Fruit length & -0.141 & 0.398 & -0.333 & 0.187 & -0.074 \\
\hline Pedicel length & -0.045 & 0.422 & -0.029 & 0.123 & -0.231 \\
\hline Placenta length & -0.275 & 0.325 & -0.109 & 0.141 & -0.014 \\
\hline Number of bifurcations & 0.098 & 0.319 & 0.297 & -0.079 & 0.549 \\
\hline Number of locules & 0.160 & 0.172 & 0.003 & -0.542 & -0.113 \\
\hline Number of seeds per fruit & 0.314 & -0.017 & -0.166 & -0.010 & -0.166 \\
\hline Average fruit weight & 0.346 & 0.120 & -0.079 & 0.123 & -0.021 \\
\hline Eigenvalue & 6.225 & 3.326 & 1.307 & 1.142 & 1.079 \\
\hline$\%$ variation explained & 36.620 & 19.560 & 7.690 & 6.720 & 6.350 \\
\hline$\%$ accumulated variation & 36.620 & 56.180 & 63.870 & 70.590 & 76.930 \\
\hline
\end{tabular}

PC: Principal component. 
The hybrid Castillo ${ }^{\circledR}$ located in Quadrant III, and G790 in Quadrant I, were placed at the end of the set, partially distant because they exhibit opposite values for the characteristics of the components. Within the complex (Group 1), individual variants were observed that expressed particular phenotypical variation without losing the peculiar characteristics of their group. The large quantity of morphotypes in the Group 1 is derived from the variability of the phenotypical attributes of their fruits. The landraces from Durango exhibited certain affinity in their dispersion (mainly Quadrant III). However, it is observed that the G734 and G735 genotypes were separated from the rest by presenting more similar characteristic values, besides having the same place of origin.

The populations G770 and VR91, as well as G734, G799 with commercial hybrid and G723, G724 together with Don Ramon (R) and Don Luis (L), indicating that these native genotypes share phenotypic similarity with improved materials, which could be associated with its morphoagronomic potential.

Group 2 associated a native population (G770) with very similar behavior and the improved variety VR91. These had short fruits and pedicels. Placenta length had intermediate values, while the Guajillo-type (G770) had higher values such as those of its plant height $(43 \mathrm{~cm})$ and fruit width $(2.1 \mathrm{~cm})$ and number of fruits per plant (43). Fruit weight $(2.1 \mathrm{~g})$, diameter $(3.8 \mathrm{~mm})$ and number of seeds (100) were similar in the two genotypes; however, the Guajillo produced fruits with acute pedicel attachment, while the Guajillo type VR91 had an obtuseangled union. The dimensions of the fruit were similar in the two native genotypes. In contrast, the improved variety had small fruits that were wider than those of genotipe G770.

In Quadrant IV, two Guajillo genotypes (G738 and G701) made up Group 3. They were medium height and had short, but very wide, few fruits with a small placenta, and acute and obtuse pedicel attachment, respectively. The fruit reached an average length of $5 \mathrm{~cm}$ and produced a large quantity of seed measuring $4.6 \mathrm{~mm}$ in diameter. Fruit weight and size of this set was superior to the Guajillo complex by $42 \%$.

G798 and G721 were positioned between Groups 1 and 3. Their placement was defined based on the intermediate values of weight, placenta length and quantity of seed, relative to Groups 1 and 3. Being from Puebla, G721 reflected differential selection, relative to the Guajillos from Zacatecas, and tended toward triangular fruits of larger dimensions and truncate union of the pedicel with the fruit. Nevertheless, the rest of the traits were similar to the broad complex of Guajillo chiles.

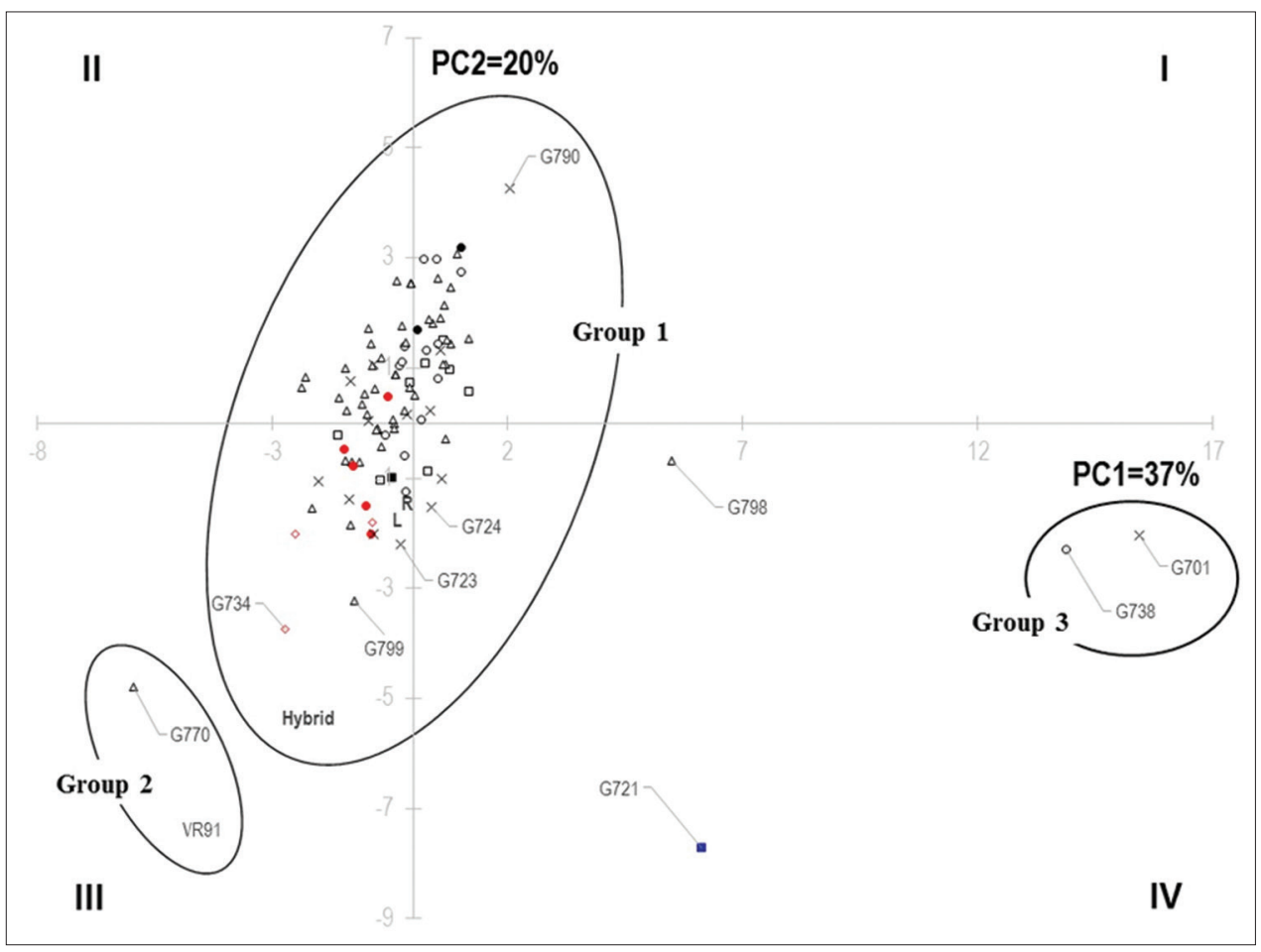

Fig 1. Dispersion of 100 Capsicum annuum L. genotypes, based on the first two principal components of the analysis of 17 morphological characteristics. The explained variation percentage by each component is shown G: Guajillo from Zacatecas (०: La Calera; $\square$ : Gral. Enrique

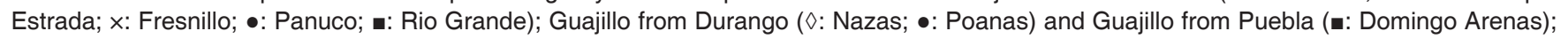
improved varieties of chile Guajillo: R: Don Ramón; L: Don Luis; VR-91: VR91; Hybrid: Castillo ${ }^{\circledR}$; PC: Principal Component. 
By the random location of the populations through the four quadrants, the population distribution of Guajillo native to Zacatecas was not associated to its geographical origin but to the morphological variation and affinity of characteristics mainly of fruit.

Grouping of variation. Based on the statistical criteria indicated by the Ward-MLM, three groups were defined (Figure 2). Grouping showed an association pattern similar to the main component analysis. All clusters maintained affinity throughout this analysis.
The association patterns were largely determined by characteristics of fruit, such as number, size, color, shape and appearance, as well as phenology.

Cluster I was clearly separated from Groups I and II (Cluster II). Its isolation was attributed to the fruit shape, since population landraces within this cluster presents triangular fruits with intermediate corrugation.

The Cluster I and II presented lower population density compared to Cluster III, which was divided into two

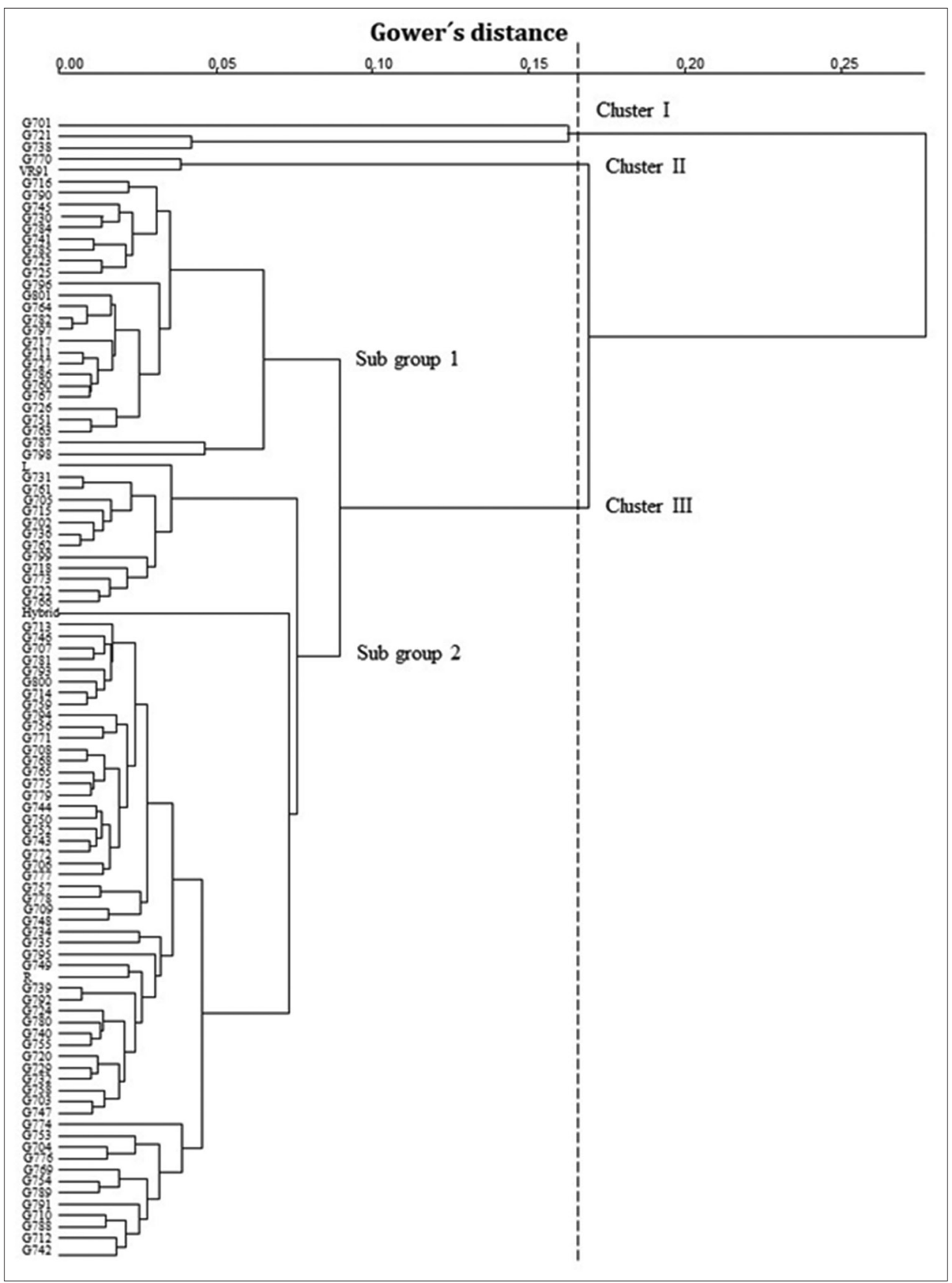

Fig 2. Dendrogram obtained with the Ward-MLM method of 100 genotypes of chile Guajillo based on 17 morphological traits selected on the basis of Gower distances. Improved varieties of Guajillo chile: R: Don Ramón; L: Don Luis; VR-91: VR91; Hybrid: Castillo ${ }^{\circledR}$. 
subgroups at a distance of 0.08 . Subgroup 1 brought together 25 populations that showed similarity in fruit characteristics as shape, size, color, number, appearance, and fruit phenology. It also included tall plants with a sturdy stem. Subgroup 2 associated the cultivars Don Luis, Don Ramon and commercial hybrid with 93 native populations. The diversity of this subgroup is considerably broad; however, the characteristics that defined its aggregation were those associated with the fruit, particularly color, fruit production and phenology, followed by plant size. Both subgroups formed the large population complex distributed in the central part of the dispersion graph (Figure 2). However, the accuracy of the Ward-MLM separated them in the dendrogram mainly due to fruit color: dark red in Sub group I and red in Sub group 2. At least one of the improved types associated with groups containing native landraces, indicating that they share genetic traits peculiar to the chile type they belong to.

\section{DISCUSSION}

In the case of the distribution of morphological diversity, the analysis of variance revealed statistical differences among genotypes, indicating the existence of broad morphological diversity. Plant, fruit and seed size, in addition to fruit shape, placenta, pedicel attachment, and fruit cross-sectional corrugation had significant contribution to the analysis of diversity. Selection of these characteristics has defined the attributes peculiar to each type of chile. Farmer criterion, together with the multiple conditions in which the crop has been grown, have defined a broad source of diversity in each landrace, particularly for the alleles of agronomic interest and of local adaptations (Nicolaï et al., 2013).

The small morphotypes with short fruits reflect management and consumer preferences of its place of provenance. Fruit characteristics provided greater explicative value for phenotypical description. According to Pardey et al. (2006), morphological diversity of the genus is described mainly by fruit characteristics: color, shape and size. This polymorphism is typical of domesticated species (Velázquez-Ventura et al., 2018). Selection of agromorphological attributes, both among and within landraces, determines the degree of morphological diversity (Castañón et al., 2008). In contrast, diversity of wild species is defined by characteristics related to foliage (VelázquezVentura et al., 2018).

Each type of chile seems to maintain their own characteristics, even though individual variants were found in Guajillo chile. This fact might be associated with gene flow due to seed exchange among farmers. The broad morphological diversity of the Guajillo complex can be associated with its capacity to exchange genes, since these landraces have an exposed style that allows cross pollination. The ability for gene exchange through crossed pollination determines the level of genetic diversity of the chile landraces and was an important factor in the process of domestication of C. annuиm L. (Geleta et al., 2005).

The differentiation efficiency of the selected quantitative and qualitative descriptors determined the formation of four genotype groups. Through highly discriminating traits, mainly of the fruit, broad morphological diversity was identified among and within the groups of the studied Guajillo chile genotypes. The native landraces share common traits associated to fruit shape and length. Yet, the Guajillo landraces from Zacatecas and Durango appear to share genetic heritage exhibited in similarity of shape and dimensions. Mainly fruit size and shape reflect different selection criteria used in the different states of origin.

About of the greater precision of the grouping of variation, this was the main advantage of the Ward-MLM method applied in this study, to determine the probability that a group would be assigned to a specific group using all of the information of the genotypes and their mixed types of traits. This allowed exact identification of the optimal number of groups (Franco et al., 2005). The genotype groups generated by the Ward-MLM were clearly perceived. Quantification of morphological diversity by analysis of mixed types of traits and ideal grouping obtained with the Ward-MLM defined genotype clusters efficiently and clearly. The method has verified the classification proposed for Capsicum and has permitted evaluation, description and representation of its broad inter- and intra-specific variation (Ortiz et al., 2010; Sudré et al., 2010). Application of the method in this analysis of diversity precisely defined groups, which corresponded to those observed by PCA. That is, the two analyses are congruent in the quantification of phenotypical diversity of the native and improved Guajillo chile. Morphological description and selection of traits, together with the simultaneous use of quantitative and qualitative descriptors by the Ward-MLM method, precisely defined population associations and differentiated morphological groups.

The morphological diversity observed in the native populations of chile Guajillo, fruit in particular, suggest a broad genetic base, with potential for incorporation into programs of genetic improvement.

\section{CONCLUSIONS}

Broad morphological diversity was found on plant, fruit and seed characteristics among Guajillo chile landraces. Placenta, pedicel, fruit cross-sectional corrugation, days to 
fruit set, and size, color, and fruit shape were the traits that had significant contribution to the analysis of the broad morphological diversity found in the Guajillo chile landraces.

\section{ACKNOWLEGMENTS}

This research was carried out with funds provided by Fundación Produce Zacatecas A.C. We thank Agronomist Javier Chávez Ávila, for his enormous interest and support for developing the research in Zacatecas.

\section{Authors' contributions}

Yolanda del Rocio Moreno-Ramírez performed the experiment, analyzed data and wrote the paper; Amalio Santacruz-Varela analyzed data and wrote the paper; Higinio López-Sánchez planned the research, designed and performed the experiment, analyzed data and wrote the paper; Leobigildo Córdova-Téllez critically reviewed the paper; Víctor A. González-Hernández critically reviewed the paper; Pedro A. López analyzed data and critically reviewed the paper; Tarsicio Corona-Torres critically reviewed the paper; Ricardo López-Ortega performed the experiment.

\section{REFERENCES}

Afzal, M., S. S. Alghamdi, H. M. Migdadi, M. A. Khan and M. Farooq. 2018. Morphological and Molecular genetic diversity analysis of chickpea genotypes. Int. J. Agric. Biol. 20: 10621070.

Aguilar-Meléndez, A., P. L. Morell, M. L. Roose and S. C. Kim. 2009. Genetic diversity and structure in semiwild and domesticated chiles (Capsicum annuum; Solanaceae) from Mexico. Am. J. Bot. 96: 1190-1202.

Bhagowati, R. R. and S. Changkija. 2009. Genetic variability and traditional practices in Naga king chili landraces of Nagaland. Asian Agric. Hist. 13: 171-180.

Castañón, N. G., M. L. Latournerie, E. M. Mendoza, L. A. Vargas and M. H. Cárdenas. 2008. Colección y caracterización de Chile (Capsicum spp) en Tabasco, México. Phyton Int. J. Exp. Bot. 77: 189-202.

Castellón-Martínez, E., J. C. Carrillo-Rodríguez, J. L. Chávez-Servia and A. Vera-Guzmán. 2016. Phenotype variation of chile morphotypes (Capsicum annuum L.) native to Oaxaca, Mexico. Phyton Int. J. Exp. Bot. 83: 225-236.

Chávez-Servia, J. L. 2006. Análisis de la diversidad dentro y entre especies de Capsicum: opciones para estimar la variación interpoblacional. In: Chávez-Servia, J. L. and R. Sevilla-Panizo, (Eds.), Fundamentos Genéticos y Socioeconómicos para Analizar la Agrobiodiversidad en la Región de Ucayali. Bioversity International, Colombia, pp. 61-75.

Contreras-Toledo, A. R., H. López-Sánchez, A. Santacruz-Varela, E. Valadez-Moctezuma, V. H. Aguilar-Rincón, T. Corona-Torres and P. A. López. 2011. Diversidad genética en México de variedades nativas de chile 'poblano' mediante microsatélites. Rev. Fitotec. Mex. 34: 225-232.

Franco, J., J. Crossa, S. Taba and H. Shands. 2005. A sampling strategy for conserving genetic diversity when forming core subsets. Crop Sci. 45: 1035-1044.

Geleta, L. F., M. T. Labuschagne and C. D. Viljoen. 2005. Genetic variability in pepper (Capsicum annuum L.) estimated by morphological data and amplified fragment length polymorphism markers. Biodivers. Conserv. 14: 2361-2375.

Gil-Muñoz, A., P. A. Lopéz, A. Muñoz-Orozco and H. López-Sánchez. 2004. Variedades criollas de maíz (Zea mays L.) en el estado de Puebla, México: Diversidad y utilización. In: Chávez-Servia, J. L., J. Tuxtill, D. I. Jarvis, (Eds), Manejo de la Diversidad de los Cultivos en los Agrosistemas Tradicionales. Instituto Internacional de Recursos Fitogenéticos, Colombia, pp. 18-25.

González-Pérez, S. A., C. Garcés-Claver, L. E. Mallor, M. Sáenz, O. Fayos, F. Pomar, F. Merino and C. Silvar. 2014. New insights into Capsicum spp relatedness and the diversification process of Capsicum annuum in Spain. PLoS One. 9: 1-23.

IPGRI-CATIE-AVRDC. 1995. Descriptores para Capsicum (Capsicum spp.). Instituto Internacional de Recursos Fitogenéticos, Italia; Centro Asiático para el Desarrollo y la Investigación Relativos a los Vegetales, Taipei, Taiwan y Centro Agronómico Tropical de Investigación y Enseñanza, Turrialba, Costa Rica.

Kraft, K. H., J. D. J. Luna-Ruíz and P. Gepts. 2010. Different seed selection and conservation practices for fresh market and dried chile farmers in Aguascalientes, Mexico. Econ. Bot. 64: 318-328.

Kraft, K. H., C. H. Brown, G. P. Nabhan, E. Luedeling, J. D. J. Luna-Ruíz, G. C. D’Eeckenbrugge, R. J. Hijman and P. Gepts. 2014. Multiple lines of evidence for the origin of domesticated chili pepper, Capsicum annuum, in Mexico. Proc. Natl. Acad. Sci. 111: 6165-6170.

Latournerie, L., J. L. Chávez, M. Pérez, G. Castañón, S. A. Rodríguez, L. M. Arias and P. Ramírez. 2002. Valoración in situ de la diversidad morfológica de chiles (Capsicum annuum L. y Capsicum chinense Jacq.) en Yaxcabá, Yucatán. Rev. Fitotec. Mex. 25: 25-33

Martínez-Sánchez, D., M. Pérez-Grajales, J. E. Rodríguez-Pérez, M. Pérez and E. del Carmen. 2010. Colecta y caracterización morfológica de "chile de agua" (Capsicum annuum L.) en Oaxaca, México. Rev. Chapingo Ser. Hortic. 16: 169-176.

Mercer, K. L. and H. R. Perales. 2010. Evolutionary response of landraces to climate change in centers of crop diversity. Evol. Appl. 3: 480-493.

Moreno-Pérez, E. C., C. H. Avendaño-Arrazate, R. Mora-Aguilar, J. J. Cadena-Iñíguez, V. H. Aguilar-Rincón and J. F. AguirreMedina. 2011. Diversidad morfológica en colectas de chile Guajillo (Capsicum annuum L.) del centro-norte de México. Rev. Chapingo Ser. Hortic.17: 23-30.

Moreno-Pérez, D. E. C., O. Cruz-Álvarez, C. H. AvendañoArrazate, M. A. T. Martínez-Damián and A. Peña-Lomelí. 2007. Morphological Variation in Guajillo Chili Pepper Plants (Capsicum annuum L.). $8^{\text {th }}$ African Crop Science Society Conference, ElMinia, Egypt, pp. 327-332.

Moreno-Pérez, E. D. C., M. T. Martínez-Damián, D. Reyes-López, C. A. Pérez-Mercado, A. Peña-Lomelí and P. Espinosa-Robles. 2006. Intensidad de color y contenido de antocianinas en chile Guajillo (Capsicum annuum L.). Rev. Chapingo Ser. Hortic. 12: $135-140$.

Nicolaï, M., M. Cantet, V. Lefebvre, A. M. Sage-Palloix and A. Palloix A. 2013. Genotyping a large collection of pepper (Capsicum spp.) with SSR loci brings new evidence for the wild origin of cultivated $C$. annuum and the structuring of genetic diversity by human selection of cultivar types. Genet. Resour. Crop Evol. 60: 2375-2390.

Ortiz, R., F. Delgado De la flor, G. Alvarado and J. Crossa. 2010. 
Classifyng vegetable genetic resources a case study with domesticated Capsicum spp. Sci. Hortic. 126: 186-191.

Pardey, R. C., M. A. D. García and F. A. C. Vallejo. 2006. Evaluación agronómica de accesiones de Capsicum del banco de germplasma de la Universidad Nacional de Colombia Sede Palmira. Acta Agron. 52: 23-28.

Petropoulos, S. A., L. Barros and I. C. Ferreira. 2019. Rediscovering local landraces: Shaping horticulture for the future. Front. Plant Sci. 10: 126.

Pla, L. E. 1986. Anáilisis Multivariado: Metodo de Componentes Principales. Secretaria General de la Organización de los Estados Americanos. Programa Regional de Desarrollo Cientifico y Tecnologico, Washington, DC.

Portis, E., A. Acquadro, C. Comino and S. Lanteri. 2004. Effect of farmers' seed selection on genetic variation of a landrace population of pepper (Capsicum annuum L.), grown in NorthWest Italy. Genet. Resour. Crop Evol. 51: 581-590.

Rivera, A, A. B. Monteagudo, E. Igartua, A. Taboada, A. García-Ulloa, F. Pomar, M. Riveiro-Leira and C. Silvar. 2016. Assessing genetic and phenotypic diversity in pepper (Capsicum annuum L.) landraces from North-West Spain. Sci. Hortic. 203: 1-11.

SAS. 2011. SAS Users Guide: Statistics. Version 9.3. Cary. SAS Institute Inc., United State.

Serna-Pérez, A., J. A. Zegbe and J. J. Mena-Covarrubias. 2011.
Rendimiento y calidad de chile seco Mirasol cultivado bajo riego parcial de la raíz. Rev. Chapingo Ser. Hortic. 17: 19-24.

SIAP-SAGARPA. 2017. Servicio de Información Agroalimentaria y Pesquera, Secretaría de Agricultura Ganadería y Desarrollo Rural, Pesca y Alimentación.

Sudré, C. P., L. S. A. Gonçalves, R. Rodrigues, A. D. Amaral Júnior, E. M. Riva-Souza and C. D. S. Bento. 2010. Genetic variability in domesticated Capsicum spp. as assessed by morphological and agronomic data in mixed statistical analysis. Genet. Mol. Res. 9: 283-294.

Toledo-Aguilar, R., H. López-Sánchez, P. Antonio López, J. D. D. Guerrero-Rodríguez, A. Santacruz-Varela and A. Huerta-de la Peña. 2011. Características vegetativas, reproductivas y de rendimiento de fruto de variedades nativas de chile "poblano". Rev. Chapingo Ser. Hortic. 17: 139-150.

Toledo-Aguilar, R., H. López-Sánchez, P. Antonio López, J. D. D. Guerrero-Rodríguez, A. Santacruz-Varela and A. Huerta-de la Peña. 2016. Diversidad morfológica de poblaciones nativas de chile poblano. Rev. Mex. Cienc. Agric. 7: 1005-1015.

Velázquez-Ventura, J. C., C. Márquez-Quiroz, E. de la CruzLázaro, L., R. Osorio-Osorio and P. Preciado-Rangel. 2018. Morphological variation of wild peppers (Capsicum spp.) from the state of Tabasco, Mexico. Emir. J. Food Agric. 30: 115-121.

Wang, D. and P. W. Bosland. 2006. The genes of Capsicum. HortSci. 41: 1169-1187.

\section{ANNEX}

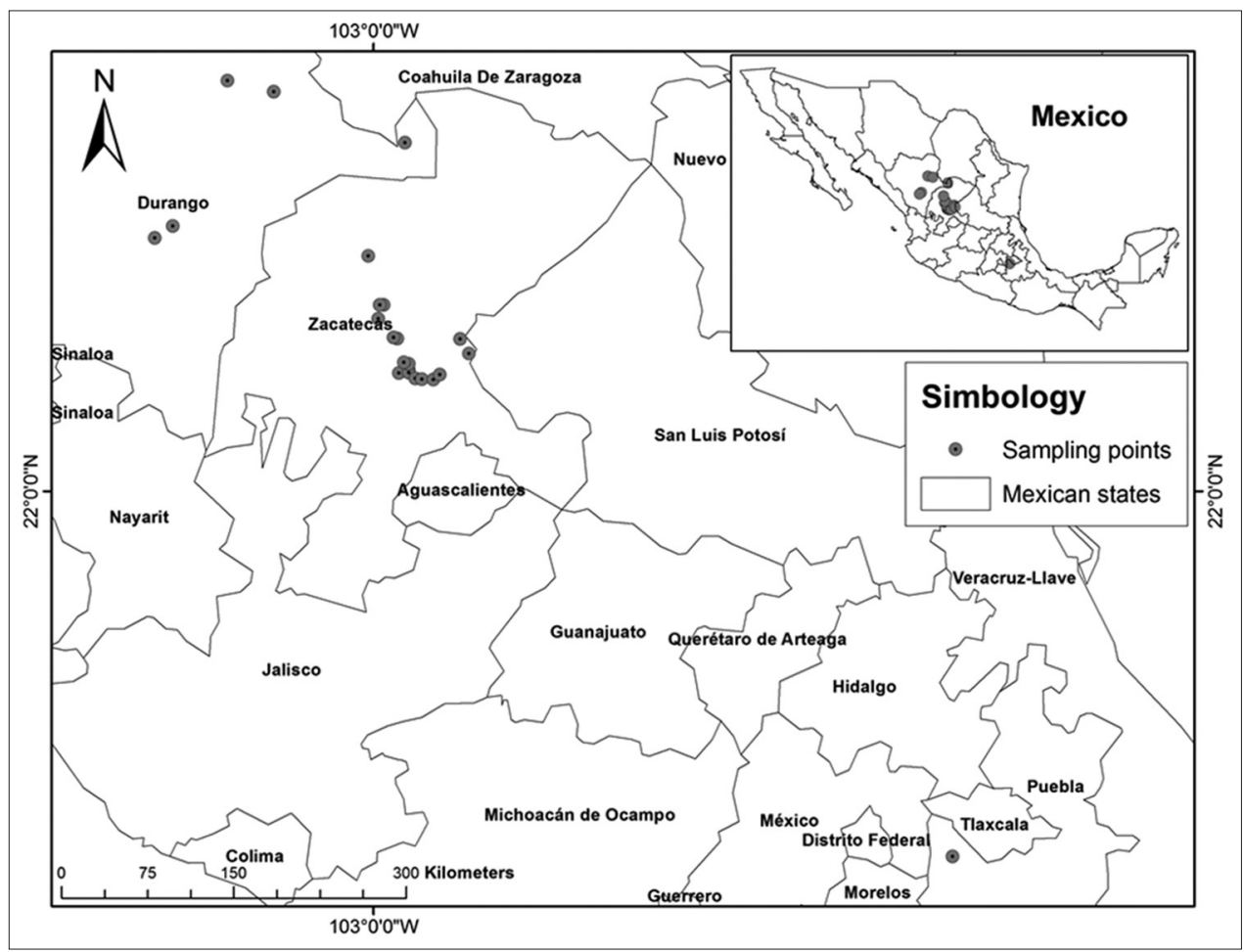

Annex 1. Geographical location of Guajillo chile (Capsicum annuum L.) landraces from Mexico. 